\title{
The Influence of Cash Flow, Leverage, and Market to Book Ratio on the Level of Dividend Payment; Study at Consumer Goods Companies Listed in Indonesia Stock Exchange (IDX) 2015-2017
}

\author{
Susfa Yetti \\ Lecturer of the Faculty of Economics and Business, University of Jambi, Jambi-36125, Indonesia \\ Afrizal \\ Lecturer of the Faculty of Economics and Business, University of Jambi, Jambi-36125, Indonesia
}

\begin{abstract}
The purpose of this study is to obtain the empirical evidence about the influence of cash flow, leverage, and market to book ratio to the level of dividend payments. The population used in this study is the consumer goods companies listed in Indonesia Stock Exchange from 2015 to 2017. The results show that Cash Flow, leverage, and market to book ratio simultaneously influence the level of dividend payment of the consumer goods companies listed in the IDX and while the market to book ratio is partially influence the level of dividend payments to the consumer goods companies listed in the IDX. There fore the bigger of the market to book ratio the bigger the dividend must be payed by the companies of the consumer goods listed in IDX.
\end{abstract}

Keywords: cash flow, leverage, market to book ratio, dividends

DOI: $10.7176 /$ RJFA/10-2-09

\section{Introduction}

I. INTRODUCTION

1.1 Background

Companies that make dividend payments indicate their financial capacity and company managers decide to signal information to investors about their hopes for future earnings by raising or lowering dividends. An implication of the conclusion above if a company that raises the dividend rate will be followed by a reaction to the increase in stock prices.

With this phenomenon, it is important to know the relationship between dividends and the factors that influence them. By knowing the factors that influence it, the information behind dividend payments will be known. It may be used by investors to make investment decisions or help managers decide on dividend payments. Investors no longer make decisions based on historical data.

The fact that managers and analysts have noticed a dividend policy, dividends must be related to something . Baker (2009), the factors that influence dividends are divided into three important categories, namely firm charismatic, market characteristic and substitute forms of payout. Firm characteristic is more influenced by fundamental firm characters such as profitability, cash flow, growth, and leverage. While the market characteristic influenced by the market conditions in which the company operates like a tax .

One study was conducted by Amidu and Abor (2006). They have conducted research to look for factors that influence the ratio of dividends in Ghana. In the study Amidu and Abor included profitability, cash flow, tax , risk, institutional holding, growth and market to book value as independent variables. With the results of the study as follows, there is a positive relationship between dividend payments and profitability, cash flow , and tax. And the negative relationship between dividend and risk payments, institutional holding, growth and market to book value .

Cash flow itself is an illustration of the company's financial position and is important in calculating dividend payments, because the stronger the liquidity position of a company will influence the company's ability to finance the company. The unfavorable position of the company's liquidity will indicate a lack of ability of the company to pay dividends.

Research conducted by Musthikawati (2010) states that book value influences dividend payments. Book Value can be seen by looking at the market to book value ratio. The higher MTB value ( market to book value) shows the tendency of higher levels of investment opportunity for companies. High MTB causes the company's retained earnings to increase or have higher liquid flexibility, so the company has the opportunity to develop the company. When developing a company, the company will prefer to use the retained earnings to develop the company rather than providing dividends to investors.

Based on the background of the problems described above and the place of research to be carried out, this study takes the title : " Influences of Cash Flow, Leverage, and Market to book ratio on Dividend Payment Levels: Study p of Consumer Goods Companies Period 2015-2017" . 


\subsection{Problem Formulation}

Based on the description above, the problems raised in this study are:

1. Is cash flow, leverage, market to book ratio simultaneous influence on the level of dividend payments in the consumer goods company listed on the Stock Exchange?

2. is Partial Cash Flow has an influence on the level of dividend payments to consumer goods companies listed in the IDX?

3. is leverage in partial influence on the level of dividend payments to consumer goods companies listed in the IDX?

4. Does the market to book ratio have a partial influence? on the level of dividend payments to consumer goods companies listed in the IDX?

\subsection{Research Purposes}

This study aims to conduct an analysis of

1. The Influence of Cash Flow, leverage , market to book ratio simultaneously towards the level of dividend payments on consumer goods companies listed in the IDX?

2. The Influence of Cash Flow on the level of dividend payments to consumer goods companies listed in the IDX?

3. The influence of leverage on the level of dividend payments to consumer goods companies listed in the IDX?

4. The influence of the market to book ratio partially to the level of payment dividends in consumer goods companies listed in the IDX?

\subsection{Benefits of Research}

This research is expected to provide benefits:

1. For investors, the results of this study can be used as one of the new discourses in considering aspects that need to be taken into account in investment .

2. For companies, can contribute ideas about the Influence of Cash Flow, leverage, market to book ratio the level of dividend payments by the company.

3. For academics, the results found in this study can be used as a reference and guideline for future researchers who are also interested in discussing the issues raised in this study.

\section{LITERATURE REVIEW}

\section{Level of dividend payment (LDP)}

Frankfurter and Wood, Jr. (2003) define dividends as distributing company earnings ( past or present ) in the form of real assets to shareholders according to their proportion of ownership. Amidu and Abor (2006) state that level of dividend payment (LDP) is the ratio between dividends per share and earnings per share. The LDP reflects the dividend policy from management regarding the amount of dividends that must be distributed to shareholders.

\section{Cash flow}

Cash flow is the amount of cash that comes out and enters the company because of the operational activities of the company. The company's cash flow can be seen from the financial statements, namely the cash flow statement. The cash flow report summarizes the cash flow in and out of the company for a certain period of time. Cash reports are needed because in some situations, the income statement is not accurate enough to describe the company's financial condition. For example, a growing company will have the following characteristics. The company has a high level of sales (eg sales are made on credit), which means it will record high income / sales (Mamduh, $2015: 33$ ).

The net cash flow of a company is different from its accounting profit, because some of the income and expenses reported in the income statement are not paid in cash throughout the year. Calculating the net cash flow of a company is by dividing net income after tax (after added depreciation and amortization) with the total assets owned by the company. Because depreciation is a non-cash expense, depreciation must be added back to net income to obtain net cash flow (Brigham and Houston, 2010: 96).

\section{Leverage}

This ratio measures a company's ability to fulfill its long-term obligations. Companies that are not solvable are companies whose total debt is greater than the total assets. This ratio focuses on the right side or company obligations. There are several types of leverage ratios that can be calculated, namely the ratio of debt to total assets, times interest earned ratio, and the ratio of fixed charge coverage. But in this measurement only the ratio of debt to total assets will be used. 
The debt to total assets ratio can be calculated by dividing the total debt by the total assets of the company. A high ratio means a company uses high debt or financial leverage. The use of high debt will increase profitability, on the other hand, high debt will also increase risk. If sales are high, the company can get high profits (because it only pays interest that is fixed). For example, leverage of $66 \%$, then PT.A uses funds of $66 \%$ of creditors (Mamduh, $2015: 41$ ).

Total debt includes all current liabilities and long-term debt. Creditors prefer lower debt ratios because the lower the debt ratio, the greater the protection of creditors' losses in the event of liquidation. On the other hand, shareholders may want more leverage because it will increase expected profits (Brigham and Houston, 2010: 143).

\section{Market to Book Value Ratio}

Market value ratio (market value ratio) relates to the company's stock price to profit, cash flow, and the value of the book. The ratio of the market price of a stock to the value of its book gives an indication of investors' views on the company. Companies that are considered good by the company (which means companies with profits and safe cash flow and continue to experience growth) are sold with a higher book value ratio than companies with low returns. First, calculate the book value per share by dividing the total equity by the number of shares outstanding (Brigham and Houston, 2010: 151). Next, divide the market price per share with the book value per share to get the market value / book value ratio (market / book value $=\mathrm{M} / \mathrm{B}$ ). Because the $\mathrm{M} / \mathrm{B}$ ratio is generally greater than 1, this means that investors are willing to pay shares greater than the value of the accounting book. This situation occurs especially when the value of assets, whether inflation or "goodwill". Thus, assets purchased several years ago at prices before inflation are recorded based on the initial acquisition price even though inflation has caused the actual asset value to rise significantly. Successful business continuity also has a value that exceeds its historical costs (Brigham and Houston, 2010: 152).

\section{Framework}

a. Influence of Cash Flow on Level of dividend payment

Amidu and Abor (2006) and Liu and Yanghong (2005) state Cash Flow often considered to influence dividend payments rather than profitability. This is because Cash Flow can reflect the company's financial position while profitability only reflects the company's income. Good cash flow position of companies makes companies better able to finance their funding sources. That way, the position of the company's Cash Flow will influence the company's ability to pay dividends. The stronger the position of the company's Cash Flow is likely to be followed by the increase in the company's dividend payment capability.

\section{b. P engaruh Leverage to Level of Dividend payment}

Leverage company is the company's financing decision in the form of debt. The higher the company's leverage will always be followed by the high debt of the company. For companies that have high debt, companies are more careful in determining the level of dividend payments, because companies that have high debts make companies prone to liquidation or fail to meet company debt payments. This makes managers more allocate company funds to debt repayments rather than dividend payments. Moreover, companies that have debt tend to have debt agreements that regulate dividend restrictions. Liu and Yanghong (2005) and Grill, Bigger and Tibrewala (2010) state the level of risk of a company influencing the level of dividend payments . High risk companies are advised to pay dividends with a smaller payment rate .

c. Influence of Market to Book Ratio on the Level of dividend payment

Grill, Bigger and Tibrewala (2010) and Mustikawati (2010) find a negative relationship between investment opportunity variables with level of dividend payment, high investment opportunities will make companies that have profits held high enough to invest. Companies that have a book value that is lower than market prices make the company can fund companies to invest.

Companies that have a large size will be very easy to get access in the capital market compared to companies that have a small size. The increasing size of the company will reduce its internal funding and the company will try to pay dividends to shareholders.

\section{Hypothesis}

H 1 : Cash Flow, Leverage, Market t o book ratio has an influence simultaneous to the level of dividend payment on consumer goods companies listed in the IDX ?

H2: Cash flow has a partial influence on the level of dividend payment in consumer goods companies listed in the IDX?

H3 : Leverage has a partial influence on the level of payment dividends in consumer goods companies listed in the IDX?

H4: Market to book ratio has a partial influence on the level of dividend payment in consumer goods companies listed in the IDX ? 


\section{RESEARCH METHODS}

\subsection{Types and Data Sources}

The data collected for this study are secondary data obtained from the Indonesia Stock Exchange website and the investment world. The data used in this study was obtained from financial reports on consumer goods companies listed in the IDX for 4 years from 2015 - 2017.

\subsection{Population and Samples}

The data population used in this study is the consumer goods companies listed on the Indonesia Stock Exchange from 2015 to 2017 . From a population of 38 companies, then a sample of 29 companies was obtained. The sampling method that will be used in this study is purposive sampling, that is, the population that will be used as the research sample is one that meets certain sample criteria in accordance with the desired and then selected based on certain considerations according to the research objectives. The criteria for sample research are:

a) Included in the company's publicly traded consumer goods in Indonesia Stock Exchange in the period from 2015 to 2017.

b) Companies that issue audited financial statements as of December 31 (12 months).

\subsection{Operational definitions of variables}

Table 4 .1.

Operational Definition of Variables

\begin{tabular}{|l|l|l|l|}
\hline No. & VARIABLES & MEASUREMENT & SCALE \\
\hline 1 & Level of dividend payment & Dividend per share / earning per share & Ratio \\
\hline 2 & Cash flow & (Net Profit after Tax + Depreciation) / Total Assets) & Ratio \\
\hline 3 & Financial leverage & Total Debt / Total Assets & Ratio \\
\hline 4 & Market to Book Value Ratio & Market Prices per Share / Book Value per Share & Ratio \\
\hline
\end{tabular}

Source: Mamduh ( 2015 ); Brigham and Houston (2006, 2010);

\subsection{Data Analysis Methods Regression Analysis}

The analysis technique used in this study is multiple linear regression, which is an analysis used to determine the influence of independent variables on the holding of company cash. In carrying out its calculations, this study uses a SPSS 21.0 tool (Statistical Product for Social Science).

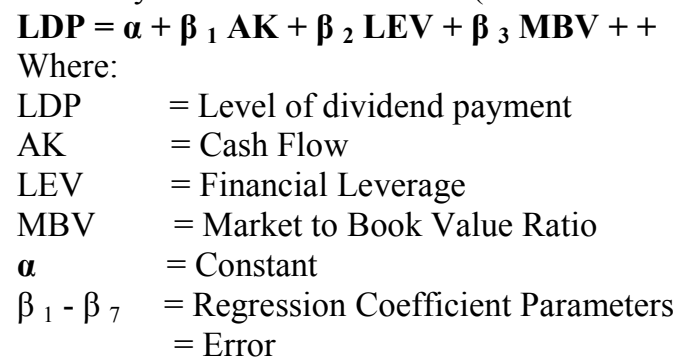

Before testing hypotheses, classical assumptions will be tested which underlie the use of the multiple regression model so that the data that will be used in hypothesis testing are free from the possibility of classical assumption deviations, which are unbiased and have minimum variance. The main classic ass according to Gujarati (200 6 ) consists of:
a. Variable normality disturbance (disturbance error)
b. Multikolinearitas
c. Autocorrelation

\subsection{Hypothesis testing}

\section{1) Test F Statistics}

To test the first hypothesis, namely whether the independent variables in the study jointly influence the dependent variable, then testing is done using the F test, to see the influence of Cash Flow, Leverag e Financial, Market to Book Value Ratio, jointly influences the level of dividend payment

\section{2) Test Statistics t}

To test the second hypothesis is done partially or called the $t$ test, which is to test the significance of the constant and the independent variables contained in the equation individually whether it influences the value of the independent variable (Gujarati, 2006). To see the influence between Cash Flow, Leverag e Financial, Market to Book Value Ratio, the partial influence on the level of dividend payment 


\section{RESULTS AND DISCUSSION}

\subsection{Descriptive analysis}

Descriptive statistics provide an overview of data, among others in the form of mean , minimum, maximum, standard deviation (Sunjoyo et al., 2017 ). The results of testing descriptive statistics in this study can be seen in table 5.1. below this:

Table 5 .1

Descriptive Statistics Table

Descriptive Statistics

\begin{tabular}{|l|r|r|r|r|r|}
\hline & $\mathrm{N}$ & \multicolumn{1}{|c|}{ Minimum } & \multicolumn{1}{c|}{ Maximum } & \multicolumn{1}{c|}{ Mean } & \multicolumn{1}{c|}{ Std. Deviation } \\
\hline Cash flow & 87 & -.95 & .44 & .1301 & .16887 \\
Financial leverage & 87 & .7 & 1.85 & .4348 & .25124 \\
Market_BV & 87 & -.29 & 46.63 & 4.6162 & 8.02713 \\
LDP & 87 & .00 & 137.71 & 21.7476 & 33.08355 \\
Valid N (listwise) & 87 & & & \\
\hline
\end{tabular}

Source: Processed Data, 2015

In table 5.1 shows the descriptive results of the variables under study. Average Cash Flow of 0.1301 with a minimum value of -0.95 which is a Cash Flow in 2012 in the company PT. Davomas Abadi Tbk (DAVO) and the maximum value of 0.44 which is Cash Flow in 2015 in the company PT. HM Sampoerna Tbk (HMSP) and with a standard deviation value of 0.16887 which means that there is a difference in the Cash Flows studied against the average value of 0.16887 .

Average Financial Leverage is 0.4348 with a minimum value of 0.07 which is a Financial Leverage in 2017 in the company PT. Davomas Abadi Tbk (DAVO) and a maximum value of 1.85 which is a Financial Leverage in 2012 at the company PT. Davomas Abadi Tbk (DAVO) and with a standard deviation value of 0.25124 which means that there is a difference in the value of Financial Leverage examined against the average value of 0.25124 .

The average Market Book Value is 0.46162 with a minimum value of -0.29 which is a Value Market Book in 2012 in the company PT. Davomas Abadi Tbk (DAVO) and a maximum value of 46.63 which is a Market Book Value in 2017 at the company PT. Unilever Indonesia Tbk (UNVR). Then the standard deviation value is 8,02713 , which means that there is a difference in the Market Book Value value that is examined against the average value of 8.02713 .

The average level of dividend payment is 21.7476 with a minimum value of 0.00 and a maximum value of 137.71 owned by the company PT. HM Sampoerna Tbk (HMSP) in 2017 and with a standard deviation value of 33.08355 which means that there is a difference in the Level of dividend payment studied against the average value of 33.0835 .

\subsection{Test of Classical Assumptions}

\section{4 .2.1 Normality test}

The results of the normality test with a probability plot graph can be seen in the picture below:

Figure 5.1

\section{Data Normality P-Plot Graph}

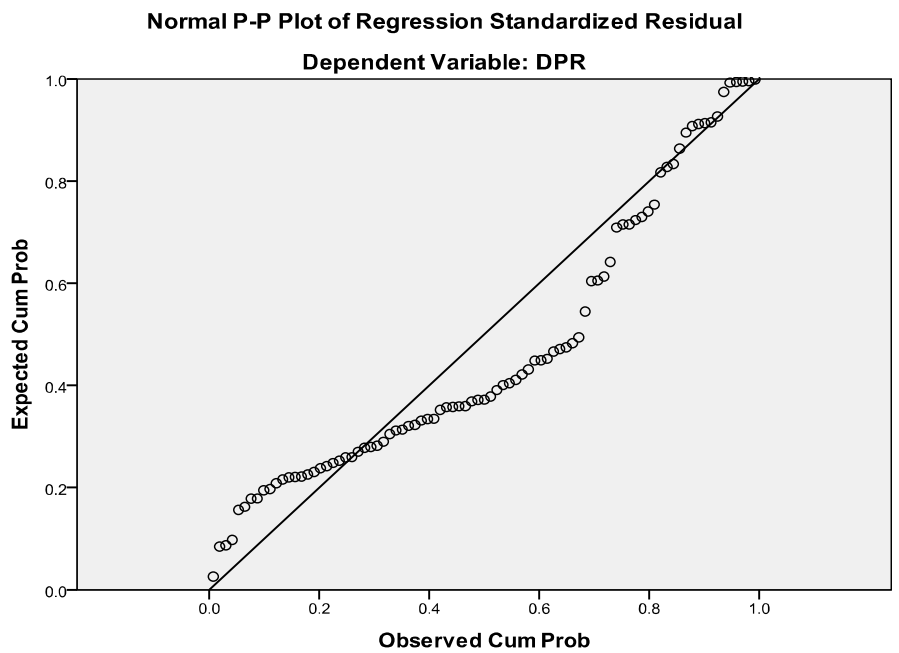

The results of the normality test as seen in the spread of data (point) on the diagonal axis of the normal 
graph of plot 4.1 follow the diagonal line so that it can be concluded that it is normally distributed.

\section{4 .2.2 Test Heteroskidastity}

The way to detect heteroscedasticity is to look at a scatterplot graph. The basis of scatterplot graph analysis if there are certain patterns such as dots that form a certain pattern that is regular (wavy, widened and then narrowed), then indicates that heteroscedasticity has occurred. If there is no clear pattern and the points spread above and below zero on the Y axis, there is no heteroscedasticity (Ghozali, 2015 ).

Figure 5.2

Heteroscedasticity Test Graph

Scatterplot

Dependent Variable: DPR

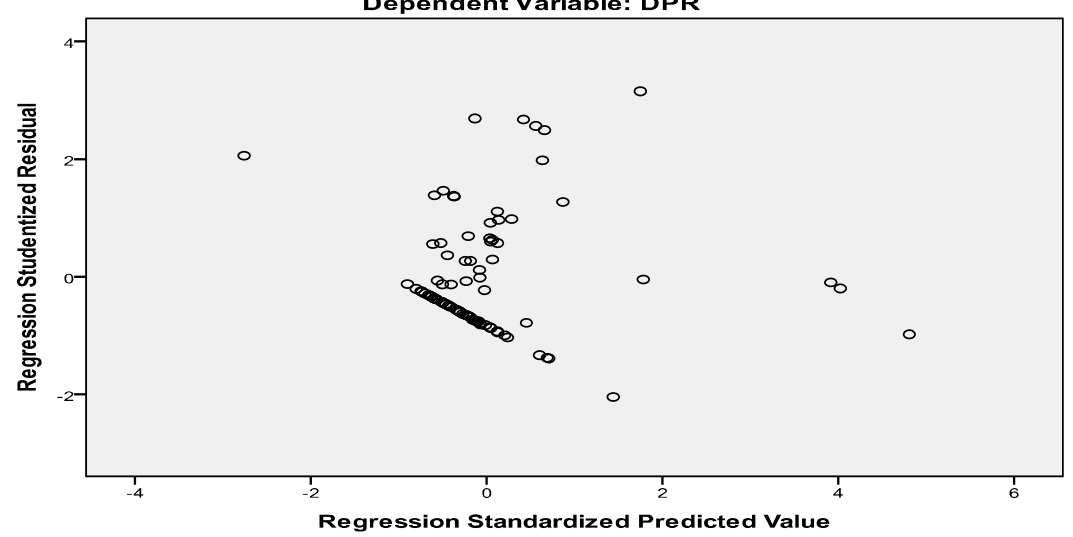

Based on the scatterplot graph analysis in Figure 5.2 above, there is no clear pattern, so that it can be stated that the data in this study did not occur heteroscedasticity.

\section{4 .2.3 Multicollinearity Test}

According to Ghozali ( 2015 ) the multicollinearity test aims to test whether there is a good regression model and there is no correlation between the independent variables. Besides the detection of multicollinearity also aims to avoid the habit in making conclusions regarding the influence of the partial test of each independent variable on the dependent variable. The results of the multicollinearity test can be seen below:

Table 5 .2

Multicollinearity Test

Coefficients $^{\text {a }}$

\begin{tabular}{|ll|r|r|}
\hline \multirow{2}{*}{ Model } & \multicolumn{2}{|c|}{ Collinearity Statistics } \\
\cline { 3 - 4 } & & Tolerance & \multicolumn{1}{|c|}{ VIF } \\
\hline 1 & (Constant) & & \\
& Cash flow & .237 & 4,227 \\
& Financial & .303 & 3,298 \\
& Market_BV & .381 & 2,627 \\
\hline
\end{tabular}

a. Dependent Variable: LDP

Source: Processed Data, 2015

A good regression model should not occur between the independent variables. Multicollinearity test can be seen with the Variance Inflation Factor (VIF) value of each of the dependent variables. If the VIF value is not more than 10, there are no symptoms of multicollinearity (Suliyanto, 2015 ). The table above shows that the independent variable has a Variance Inflation Factor (VIF) value below 10, so it can be concluded that there are no symptoms of multicollinearity.

\section{4 .2.4 Autocorrelation Test}

Autocorrelation is a condition when an error term at a certain period correlates with a disturbing factor in another period. A good regression model is a regression that is free from autocorrelation (non autocorrelation). Testing the symptoms of autocorrelation is done by the Durbin-Watson test, if the DW value is between 1,724-2,276 then autocorrelation does not occur (Ghozali, 2015 ). 


\section{Table 5.3}

Autocorrelation Test Results

Model Summary ${ }^{\text {b }}$

\begin{tabular}{|l|c|r|r|r|r|}
\hline Model & $\mathrm{R}$ & $\mathrm{R}$ Square & Adjusted R Square & Std. Error of the Estimate & Durbin-Watson \\
\hline 1 & $.622^{\mathrm{a}}$ & .387 & .365 & 26.37094 & 1930 \\
\hline
\end{tabular}

a. Predictors: (Constant), Market_BV, Financial, Arus_Kas

b. Dependent Variable: LDP

Based on the test results, the value of Durbin-Watson obtained is 1.930. This value is located between 1,724-2,276. It can be concluded that there are no symptoms of autocorrelation in this study.

\section{4 .3 Data Analysis Methods}

\section{4 .3.1 Multiple Linear Regression Analysis}

Analysis of the data used in the study is multiple regression analysis with the help of computers through the SPSS 19.0 for Windows multiple regression program based on functional or causal relationships of more than one independent variable with one dependent variable (Sugiyono, 2015 ). The equation used is as follows:

$\mathrm{Y}=\mathrm{a}+\mathrm{b}_{1} \mathrm{X}_{1}+\mathrm{b}_{2} \mathrm{X}_{2}+\mathrm{b}_{3} \mathrm{X}_{3}+\mathrm{e}$

The following are the results of testing multiple linear regression presented in the table below:

Table 5.4

Results of Multiple Linear Regression

Coefficients ${ }^{\text {a }}$

\begin{tabular}{|l|r|r|r|}
\hline \multirow{2}{*}{ Model } & \multicolumn{2}{|c|}{ Unstandardized Coefficients } & Standardized Coefficients \\
\cline { 2 - 4 } & \multicolumn{1}{|c|}{ B } & Std. Error & Beta \\
\hline (Constant) & 23,236 & 11,398 & \\
Cash flow & 1,097 & 34,623 & .006 \\
Financial & $-30,571$ & 20,555 & -.232 \\
Market_BV & 2,526 & .574 & .613 \\
\hline
\end{tabular}

a. Dependent Variable: LDP

Air ity information in Table 5.4 the regression equation as follows:

$$
Y=23,236+1,097 X_{1}-30,571 X_{2}+2,526 X_{3}
$$

Based on the linear regression equation can be interpreted as follows:

1. A constant of 23,236 gives the meaning that if the Cash Flow $\left(\mathrm{X}_{1}\right)$, Financial Leverage $\left(\mathrm{X}_{2}\right)$, Market Book Value $\left(\mathrm{X}_{3}\right)$, book value $\left(\mathrm{X}_{4}\right)$ is assumed to be 0 , then the Level of dividend payment $(\mathrm{Y})$ is worth 23,236 .

2. The regression coefficient of the Cash Flow variable $\left(\mathrm{X}_{1}\right)$ of 1.097 means that this indicates that by adding one unit of Cash Flow there will be an increase in the Level of dividend payment of 1.097. And vice versa.

3. The regression coefficient of Financial Leverage variable $\left(\mathrm{X}_{2}\right)$ is $-30,571$, which means that this indicates that with the addition of one unit of Financial Leverage there will be a decrease in the Level of dividend payment of $-30,571$. And vice versa.

4. The Market Book Value variable regression coefficient $\left(\mathrm{X}_{3}\right)$ is 2.526 meaning that this indicates that by adding one Market Book Value unit, there will be an increase in the Level of dividend payment of 2.526.

And vice versa.

\subsubsection{Hypothesis Test}

Hypothesis testing is done with using SPSS 19.00 for windows and the test equipment in the form of multiple linear regression, so that it can be seen the influence between the independent variables on the dependent variable.

\section{Test F Statistics}

To find out the significant influence is through calculations that can be used to accept or reject the formulated hypothesis, namely by looking at the significance of each independent variable with a significance level of $\alpha=$ 0.05. If the significance level is less than $\alpha=0.05, \mathrm{H} 0$ is rejected or partially $\mathrm{Ha}$ accepted means of the independent variables significantly influence the dependent variable.

Basis for a decision to determine $\mathrm{H}_{0}$ and $\mathrm{Ha}$ accepted is with the following criteria:

If $\mathrm{F}_{\text {count }}>\mathrm{F}_{\text {table }}$, means $\mathrm{H}_{0}$ is rejected

If $\mathrm{F}_{\text {count }}<\mathrm{F}_{\text {table }}$, it means that $\mathrm{H}_{0 \text { is }}$ accepted 
The following are the results of the F static test which are presented in the table below:

Table 5.5

F Statistic Test Results

ANOVA b

\begin{tabular}{|c|c|c|c|c|c|}
\hline Model & Sum of Squares & df & Mean Square & $\mathrm{F}$ & Sig. \\
\hline $1 \quad$ Regression & 36408,448 & 3 & 12136,149 & 17.451 & $.000^{\mathrm{a}}$ \\
\hline Residual & 57720.404 & 83 & 695,427 & & \\
\hline Total & 94128,852 & 86 & & & \\
\hline
\end{tabular}

a. Predictors: (Constant), Market_BV, Financial, Arus_Kas

b. Dependent Variable: LDP

Based on table 4.5, it can be explained that the $\mathrm{F}$ count value is 17.451 with a p-value of 0,000 and the calculated $F$ value is greater than the value of the $F_{\text {table }}(17.451>2.71)$. Thus $\mathrm{H}_{0}$ is rejected and download erima $\mathrm{H}_{\mathrm{a}}$. From these results it can be stated that simultaneously Cash Flow, Financial Leverage, and Market Book Value influence the Level of dividend payment.

T test

To find out whether the influence is significant or not is through a calculation that can be used to accept or reject the formulated hypothesis, namely by looking at comparing the value of $t_{\text {count }}$ with $\mathrm{t}$ table at a $95 \%$ confidence level $(\alpha=0.05)$, with the decision criteria:

- If $\mathrm{t}_{\text {count }}<\mathrm{t}_{\text {table }}: \mathrm{H}_{0}$ is accepted or $\mathrm{H}_{\alpha \text { is }}$ rejected

- If $\mathrm{t}_{\text {count }}>\mathrm{t}_{\text {table }}: \mathrm{H}_{\alpha \text { is }}$ accepted or $\mathrm{H}_{0 \text { is }}$ rejected

Another alternative that can be used to accept or reject the formulated hypothesis, namely by looking at a significance smaller than 0.05 then $\mathrm{H}_{0}$ rejected or $\mathrm{H}_{\alpha}$ accepted means that the independent variable partially has a significant influence on the dependent variable (Ghozali, 2015 ).

The following are the results of the static test $\mathrm{t}$ presented in the table below.

\section{Table 5.6}

Statistical Test Results $t$ Coefficients $^{\text {a }}$

\begin{tabular}{|c|c|c|c|}
\hline \multicolumn{2}{|c|}{ Model } & $\mathrm{t}$ & Sig. \\
\hline \multirow[t]{4}{*}{1} & (Constant) & 2,039 & .45 \\
\hline & Cash flow & .032 & .975 \\
\hline & Financial & -1.487 & .141 \\
\hline & Market_BV & 4,399 & .000 \\
\hline
\end{tabular}

a. Dependent Variable: LDP

Based on table 4.6 it can be explained that hypothesis testing is as follows:

1. Testing the regression coefficient of variable Cash Flow $\left(\mathrm{X}_{1}\right)$

The value of $t_{\text {count }}$ variable Cash Flow $\left(\mathrm{X}_{1}\right)$ is smaller than $1.9876\left(\mathrm{t}_{\text {table }}\right)$ which is equal to 0.032 and positive direction. The significance level of the Cash Flow variable $\left(\mathrm{X}_{1}\right)$ is $0.975(>0.05)$. Thus H0 is accepted and $\mathrm{H}_{\mathrm{a}}$ is rejected. From these results can be stated that partially Cash Flow does not influence the Level of dividend payment.

2. Testing the regression coefficient of Financial Leverage variables $\left(\mathrm{X}_{2}\right)$

The value of $\mathrm{t}_{\text {count }}$ Financial Leverage variable $\left(\mathrm{X}_{2}\right)$ is smaller than $1.9876\left(\mathrm{t}_{\text {table }}\right)$ which is equal to -1.487 and negative direction. The significance level of the Financial Leverage variable $\left(\mathrm{X}_{2}\right)$ is $0.141(>0.05)$. Thus $\mathrm{H} 0$ is accepted and $\mathrm{H}_{\mathrm{a}}$ is rejected. From these results it can be stated that partially Financial Leverage has no influence on Level of dividend payment.

3. Market Book Value variable regression coefficient testing $\left(\mathrm{X}_{3}\right)$

The value of $\mathrm{t}_{\text {count }}$ Market Book Value variable $\left(\mathrm{X}_{1}\right)$ is smaller than $1.9876\left(\mathrm{t}_{\text {table }}\right)$ which is equal to 4,399 and has a positive direction. The significance level of the Market Book Value variable $\left(\mathrm{X}_{3}\right)$ is 0,000 $(<0.05)$. Thus $\mathrm{H} 0$ and $\mathrm{H}_{\text {a }}$ megrim dit dit erima. From these results it can be stated that partially Market Book Value influence on level of dividend payment.

From the hypothesis testing it can be concluded that the results are as follows: 
Table 5.7

Results of the Hypothesis Test Summary

\begin{tabular}{|c|c|c|c|c|c|c|}
\hline No. & Hypothesis & $\mathrm{t}_{\text {table }}$ & $\mathrm{t}_{\text {count }}$ & $\mathrm{F}$ & $\mathrm{F}_{\text {count }}$ & Results \\
\hline 1. & $\begin{array}{l}\text { Cash Flow, Financial Leverage, Market Book Value and } \\
\text { book value simultaneously influence level of dividend } \\
\text { payment. }\end{array}$ & & & 2.71 & 17.451 & $\begin{array}{l}\mathrm{Ha} \\
\text { accepted }\end{array}$ \\
\hline 2. & Cash Flow has no influent on Level of dividend payment. & 1.9876 & 0.032 & & & $\begin{array}{l}\mathrm{Ha} \text { is } \\
\text { rejected }\end{array}$ \\
\hline 3. & $\begin{array}{l}\text { Financial Leverage has no influence on level of dividend } \\
\text { payment. }\end{array}$ & 1.9876 & $\begin{array}{c}- \\
1,487\end{array}$ & & & $\begin{array}{l}\mathrm{Ha} \text { is } \\
\text { rejected }\end{array}$ \\
\hline 4. & $\begin{array}{l}\text { H } 4 \text { : } \\
\text { Market Book Value influences the Level of dividend } \\
\text { payment. }\end{array}$ & 1.9876 & 4,399 & & & $\begin{array}{l}\mathrm{Ha} \\
\text { accepted }\end{array}$ \\
\hline
\end{tabular}

The coefficient of determination $\left(R^{2}\right)$

The coefficient of determination $\left(\mathrm{R}^{2)}\right.$ done to see how far the model's ability to explain the variation of the dependent variable (Ghozali, 2015 ). According Ghozali (2015) fundamental flaws using the coefficient of determination $\left(\mathrm{R}^{2)}\right.$ is biased against the number of independent variables were entered into the model. Every additional one independent variable, then $\mathrm{R}^{2}$ definitely increases no matter whether the variable has a significant influence on the dependent variable. Therefore many researchers recommend using the Adjusted R Square value when evaluating which best regression model. Unlike $\mathrm{R}^{2}$, the Adjusted R Square value can go up or down if one independent variable is added to the model.

The following is the result of testing the coefficient of determination presented in the table below:

Table 5.8

\section{Coefficient of Determination} Model Summary ${ }^{b}$

\begin{tabular}{|l|c|r|r|r|}
\hline Model & $\mathrm{R}$ & $\mathrm{R}$ Square & Adjusted R Square & Std. Error of the Estimate \\
\hline 1 & $.622^{\mathrm{a}}$ & .387 & .365 & 26.37094 \\
\hline
\end{tabular}

a. Predictors: (Constant), Market_BV, Financial, Arus_Kas

b. Dependent Variable: LDP

Based on the table above, the Adjusted R Square number is 0.365 or $36.5 \%$. This shows that Cash Flow, Financial Leverage, and Market Book Value variables can influence Level of dividend payment by $36.5 \%$ while the remaining $63.5 \%$ is influenced or explained by other variables not included in this research model.

\subsection{Discussion}

\subsubsection{The Influence of Cash Flow on Level of dividend payment}

Aruskas no influence on the level of dividend payment results support previous research carried out by Endang and Minaya (2005) also found that the cash flows are not air influence on the level of dividend payment (LDP).

This study found that the size of free cash flow does not influence the high and low distribution of $d$ ividends. If the company wants to maximize shareholder wealth by distributing dividends while free cash flow conditions are not possible, companies can use external funding. In accordance with the Pecking Order Theory concept which suggests that companies tend to prioritize internal funding to pay dividends if the funding needs are less then external funds are used in addition.

The condition of a company with a high level of cash flow can influence the dividend policy decided. If the growth rate of the company is low but has a high Cash Flow, it is better that the available cash be allocated as dividends. But if the company's growth rate is high, and excess available cash, it would be better if the cash is used for the growth of the company, because in the end the results of the use of cash will double.

This research contradicts the research conducted by Amidu and Abor (2006) Liu and Yanghong (2005) and Rosdini (2009) who find that Cash Flow has an influence on the Payment Dividend Rate (LDP). P enelitian Kouki and Guizani (2009) which states that the company has cash flow that tend dividends are high as well .

\subsubsection{The Influence leverage against the level of dividend payment}

Leverage does not influence level of dividend payment This result is supported by research The results of this study are consistent with the research conducted by Kuwari (2010), stating that leverage has no influence and is not significant on the dividend policy and research of Suharli and Megawati in Arilaha (2009) which shows that firms those with high operating or financial leverage will give low dividends.

The amount of financial leverage depends on the size of the interest expense due to the existence of loan 
capital (debt). The higher the financial leverage, the higher the financial risk that must be borne by the company. Therefore, the existence of low financial leverage will be more profitable for the company because it can produce maximum profits for shareholders.

Companies that have a capital structure consisting of creditors and shareholders, where management does not only pay attention to debtholder interests in the form of repayment of obligations but also pay attention to the interests of shareholders by distributing dividends. The contracting efficiency perspective states that managers tend to choose policies that can minimize agency costs, so that the policies taken can be accepted by shareholders and management.

The results of this study contradict the research conducted by Grill, Bigger and Tibrewala (2010) Karami ( 2017 ) and Asif et. al ( 2015 ) shows that leverage influences the debt to equity ratio . High risk companies are advised to pay dividends with a smaller payment rate.

\subsubsection{The Influence of Market Book Value of the level of dividend payment}

Market Book Value variables partially have a positive influence on dividend policy. In line with Mustikawati's research (2010). High Market Book Value will increase their payout dividends . So even though the company's investment funds increase, the company continues to provide dividends to investors as an appreciation to investors. this could also be the result of high investment funds not being followed by investment opportunities in the market which caused the company's funds to accumulate, so that investors would prefer to return their funds in the form of dividends. The results of this study are contrary to the research conducted by Gri 1l, Bigger and Tibrewala (2010).

\section{CONCLUSION AND SUGGESTION}

\subsection{Conclusions}

Based on the results of the research and discussion that have been conducted, it can be concluded as follows:

1. Cash Flow, leverage, market to book ratio simultaneously influence the level of dividend payments on the consumer goods companies listed in the IDX.

2. Cash Flow partially does not influence the level of dividend payments on the consumer goods companies listed in the IDX.

3. Leverage partially has no influence on the level of dividend payments on the consumer goods company listed in the IDX

4. The Market to book ratio has an influence on the level of dividend payments on the consumer goods companies listed in the IDX.

5. There fore the bigger of the market to book ratio the bigger the dividend must be payed by the companies of the consumer goods listed in IDX.

\subsection{Suggestions}

Referring to the results of the analysis and conclusions of the study, the following suggestions can be put forward:

1. For investors

For investors who want to invest their capital to get dividends in a company, they can see the market to book ratio because based on the results of the research the variables that have a significant influence on dividend policy are the Market to book ratio .

2. For the company

This research is expected to be useful for companies, especially company management, the results of this study are expected to be taken into consideration in making dividend distribution decisions to shareholders.

\section{References}

Arilaha, Muhammad A. ${ }^{3}$ Influences of Free Cash Flow, Profitability, Liquidity and Leverage on Dividend Policy' '. Journal of Finance and Banking. Vol. 13 No. 1, p. 78-87. 2009. Endang \& Minaya. 2005. Influence of Insider Ownership, Dispersion of Ownership, Free Cash Flow, Collaterizable Assets and Growth Rate on Dividend Policy. Journal of Economics and Business , Vol. 14, No.21.

Karami, Lalu Candra. ${ }^{3}$ "7 KICIC'l, 1 ence Of Liquidity and Leverage on Policy Dividend (Empirical Study on Listed Companies in Indonesia Stock Exchange of LQ45 in 2008-2010) ' . Brawijaya University Scientific Journal Vol.1 No.1. 2017 .

Asif, Aasia, Waqas Rasool and Yasir Kamal. ${ }^{3}$ Impact of financial leverage on dividend policy: Empirical evidence from Karachi Stock Exchange listed FRP SUQiIE . African Journal of Business Management Vol. 5, pp. 1312-1324. ISSN 1993-8233 Academic Journals. 2015.

Yunita, NS 2008. Influence of Free Cash Flow, Profitability, and Debt on Dividend Payment Levels .. Universitas Brawijaya. Poor.

Rosdini, D. 2009. "Influence of Free Cash Flow on Divident Payout Ratio". Working Paper in Accounting and 
Finance.

Arvitricia, R. 2010. Analysis of the Influence of Free Cash Flow, Leverage, Company Value, Company Size, and Ownership Structure of Dividend Amount: Case Study of Non-Financial Companies in the IndonesiaStock Exchange 2003-2007. University of Indonesia Thesis Not published.

Kieso, DE, Weygandt, JJ, and Warfield, TD 2007. Intermediate Accounting 12 years . Asia: John Wiley \& Sons (Asia) Pte Ltd

Subramanyam, KR, and Wild, JJ 2009. Financial Statement Analysis $10^{\text {th }}$ ed. Singapore: Mc Graw Hill. Sugiarto. 2008. "Policy-Corporate Dividend Non-Financial Public Company controlled All family has". Accountability. March 2008. PP. 135-149.

Kouki, M., and Guizani, M. 2009. "Ownership Structure and Dividend Policy Evidence from the Tunisian Stock Market" . European Journal of Scientific Research. ISSN 1450-216X. Vol. 25. No. 1 (2009). Pp. $42-53$.

Brigham, EF and Houston, Joel F. 2010. Basic Basic Financial Management, Volume 1 .Jakarta: Salemba Four.

Moradi, Melhi, et al. 2009. Factors Influenceing Dividend Policy: Empirical Evidence of Iran. UDK / UDC: $336.76(55)$.

Al-Kuwari, Duha. 2010. To Pay or Not to Pay: Using Emerging Data Panel to Corporate Dividend Payout Decision IdentifyFactors Influencing. International Research Journal of Finance and Economics. ISSN 1450-2887 Issue 42.

Arilaha, MA Influence of Free Cash Flow, Profitability, Liquidity, and Leverage on Dividend Policy. Journal of Finance and Banking.Vol. 13.No. 1 .Januari 2009, p 78- 87.Ternate.

Amidu, Mohammed and Abor, Joshua.2006.Determinants of Level of dividend payment in Ghana. Vol. 7, No.2, pp 136-145

First Author: Susfa Yetti (HA'02-HA'06-HMA'10). Head of Accounting Departement at Faculty of Economic in Jamby University (2002 - 2006-2010), Head of Master Accounting Departement at Jambi University Birth : October 6, 1969 Bukittinggi, Indonesia. Education: Bachelor in Accounting at Faculty of Economics of Andalas University, Padang, Indonesia. Master in Accounting 1997 of Padjadjaran University, Bandung, Indonesia.

Second Author: Afrizal (D’04-D’08--CH '15--‘19). Dean of Economics Faculty of Jambi University (20042008), Dean of Economics Faculty of Jambi University (2008-2012), Chairman of Indonesia Accountants Institute for Jambi Province (2015-2019). Birth: 27 July 1959 Bukittinggi, Indonesia. Education: Bachelor in Accounting at Andalas University, Padang, Indonesia. Master in Accounting 1996 at Padjadjaran University, Bandung, Indonesia. Doctor in Accounting 1999 at Padjadjaran University, Bandung, Indonesia. 